\title{
IMPLEMENTASI MANAJEMEN BANDWIDTH DENGAN DISIPLIN ANTRIAN HIERARCHICAL TOKEN BUCKET (HTB) PADA SISTEM OPERASI LINUX
}

\author{
Muhammad Nugraha \\ Program Studi Teknik Informatika UNIDA Gontor \\ JIn. Siman KM 6, Siman, Ponorogo, Jawa Timur \\ e-mail :mnugraha@unida.gontor.ac.id
}

\begin{abstract}
Important Problem on Internet networking is exhausted resource and bandwidth by some user while other user did not get service properly. To overcome that problem we need to implement traffic control and bandwidth management system in router. In this research author want to implement Hierarchical Token Bucket algorithm as queue discipline (qdisc) to get bandwidth management accurately in order the user can get bandwidth properly. The result of this research is form the management bandwidth cheaply and efficiently by using Hierarchical Token Bucket qdisc on Linux operating system were able to manage the user as we want.
\end{abstract}

Keywords : traffic control, Hierarchical Token Bucket, bandwidth management, linux.

\section{Abstrak}

Masalah terpenting dari jaringan internet salah satunya adalah habisnya sumberdaya jaringan dan bandwidth oleh sejumlah pengguna tertentu sementara pengguna-pengguna yang lain tidak dapat memperoleh layanan yang semestinya mereka dapatkan. Untuk menanggulangi hal tersebut perlu diterapkannya traffic control dan sistem pengaturan bandwidth pada router. Pada penelitian ini penulis ingin menerapkan algoritma Hierarchical Token Bucket sebagai disiplin antriannya untuk mendapatkan pengaturan bandwidth yang akurat, sehinga pengguna layanan dapat mendapatkan bandwidth sebagaimana mestinya. Hasil akhir dari penelitian ini adalah terbentuknya suatu manajemen bandwidth yang murah dan efisien dengan menggunakan disiplin antrian Hierarchical Token Bucket pada Sistem Operasi Linux yang mampu mengatur penggunaan bandwidth sesuai dengan diinginkan.

Kata Kunci : traffic control, Hierarchical Token Bucket, manajemen bandwidth, linux.

\section{PENDAHULUAN}

Layanan komunikasi data telah menjadi sangat penting dalam kehidupan sehari-hari. Hampir disetiap bidang kehidupan telah menggunakan layanan ini. Layanan inipun tidak hanya digunakan secara individual tetapi juga digunakan oleh banyak pengguna. Banyak sekali organisasi atau lembaga yang menggunakan akses Internetnya dengan banyak pengguna seperti lembaga pendidikan, perkantoran, usaha Internet, dll. Penggunaan akses Internet dengan banyak pengguna akan mengakibatkan turunnya performance jaringan dimana sebagian pengguna akan mendominasi pemakaian bandwidth sedangkan sebagian yang lain sulit untuk mendapatkan bandwidth yang semestinya diperoleh. Pengaturan bandwidth perlu diterapkan sedemikian rupa sehingga setiap pengguna bisa mendapatkan bandwidth dengan semestinya sesuai dengan rancangan yang dikehendaki. Hal ini akan lebih penting lagi jika di lingkungan usaha atau komersial, dimana penyedia layanan harus memastikan bahwa pelanggan mendapatkan layanan sesuai dengan konvensasi yang diberikan.

Seperti yang kita tahu banyak sekali perangkat khusus pengatur traffic atau bandwidth komersial yang beredar di pasaran seperti Cisco dan Mikrotik. Kemampuan perangkat khusus tersebut dari segi performance sudah teruji dan berjalan baik, akantetapi perangkat khusus 
tersebut dari segi harga cukup mahal dan hal ini akan cukup memberatkan bagi lembaga yang tidak memiliki dana yang cukup besar.

Quality of Service (QoS) memegang peranan yang sangat penting dalam hal ini. Linux sebagai suatu sistem operasi yang bersifat open dan free, telah menawarkan berbagai teknik QoS untuk memfasilitasi proses manajemen bandwidth pada suatu jaringan. Salah satunya adalah dengan menggunakan disiplin antrian Hierarchical Token Bucket (HTB), yang menjamin para pengguna jaringan mendapatkan bandwidth yang sesuai dengan yang telah didefinisikan, dan juga terdapat fungsi pembagian bandwidth yang adil diantara para pengguna jaringan sehingga performance jaringan tetap dapat terjaga.

Pada saat ini sudah ada beberapa penelitian yang sudah dilakukan mengenai manajemen bandwidth, diantaranya adalah penelitian yang dilakukan oleh Purwaka I.A. dengan judul penelitian "Perencanaan dan Implementasi Manajemen Proses Jaringan pada Warnet", yang pada penelitiannya itu perancangannya menekankan pada LAN warnet, sehingga traffic yang dimonitoring ataupun dianalisa adalah traffic yang terjadi pada workstation atau yang melewati gateway dari jaringan warnet. Dan dari hasil penelitiannya itu didapat gambaran bahwa saat terjadi dominasi penggunaan bandwidth oleh workstation tertentu dalam suatu jaringan, hal ini akan mempengaruhi kecepatan dan kelancaran akses Internet dari workstation lain. Sehingga diharapkan nantinya manajemen proses jaringan pada warnet dapat lebih dikembangkan pada tataran yang lebih yaitu pada proses network remote monitoring. Penelitian lain yang sudah dilakukan adalah "Implementasi Differentiated Service (Diffserv) DiJaringan Testbed Menggunakan Disiplin Antrian Priority Queuing (PQ) dan Hierarchy Token Bucket (HTB)" oleh Pramudita D.A., yang mengimplementasikan Differentiated Service (DiffServ) pada jaringan testbed, mengukur dan menganalisis parameter-parameter kualitas layanan jaringan berbasis DiffServ, serta mencari disiplin antrian yang mampu memberikan layanan paling sesuai dengan kebutuhan kelas traffic Expedited Forwarding (EF) dan Assured Forwarding (AF). Hasil pengujiannya memperlihatkan bahwa DiffServ mampu mengklasifikasikan traffic ke dalam kelas-kelas yang sesuai dan memberikan pelayanan yang berbeda diantara kelas-kelas traffic tersebut. Hasil pengujian juga menunjukkan bahwa pemberian prioritas pertama pada traffic menggunakan disiplin antrian PQ menghasilkan kinerja layanan yang mampu memenuhi kebutuhan kelas traffic EF, yaitu waktu tunda, jitter, dan paket hilang yang kecil. Sedangkan penerapan disiplin antrian HTB memberikan kinerja layanan yang paling sesuai untuk memenuhi kebutuhan kelas traffic AF, yaitu pembagian dan penjaminan kapasitas jaringan untuk masing-masing kelas.

Berdasarkan dari beberapa penelitian sebelumnya mengenai manajemen bandwidth maka pada penelitian ini akan dibangun sistem yang lebih mudah tetapi memberikan hasil yang optimal. Sistem yang akan dibangun berupa sebuah manajemen bandwidth dengan disiplin antrian menggunakan Hierarchical Token Buket (HTB) dengan sistem operasi Linux dan tool konfigurasinya menggunakan iproute2 suite dan netfilter iptables. Titik beratnya penelitian ini mengarah kepada pengaturan kapasitas bandwidth bagi komputer client, dengan kriteria-kriteria filter dan prioritas berdasarkan alamat IP asal, alamat IP tujuan, port asal dan port tujuan (port TCP / port UDP).

\section{METODE PENELITIAN}

Pada penelitian ini akan dilakukan percobaan menggunakan $1 P C$ dengan sistem operasi linux sebagai router yang berfungsi untuk memanage bandwidth, memonitor dan mengcapture traffic, dan untuk memblock service-service yang tidak diinginkan. Selain itu untuk mendapatkan data yang diinginkan dibutuhkan $30 P C$ yang nantinya akan di setting sedemikian rupa sehingga bisa mendapatkan hasil data yang akurat dan bisa dipertanggungjawabkan. Sistem yang akan di bangun ini tujuannya adalah untuk menjamin dan meastikan bahwa setiap client yang menggunakan sumber daya jaringan akan mendapatkan jumlah traffic baik yang lokal maupun dari Internet sebagai mana mestinya. Selain setiap client akan dijamin medapatkan bandwidth sesuai yang dialokasikan, sistem juga akan di setting bisa mendapatkan bandwidth lebih dari yang dialokasikan dengan syarat bandwidth yang tersedia dari sumber/pusat ada yang sedang tidak digunakan. Dengan kata lain bandwidth yang tidak di pakai tersebut di pinjam oleh client yang sedang membutuhkan bandwidth lebih besar dan bandwidth akan kembali seperti semula 
atau berkurang ketika ada client lain yang akan memakai bandwidth juga. Adapun untuk tools yang digunakan pada penelitian ini antara lain: sistem operasi Linux, disiplin antrian HTB, SFQ, dan FIFO, iproute2 suite, netfilter iptables, cacti, PHP-5, MySQL, apache, rrdtool, snmp, iftop. Karena keterbatasan kemampuan infrastruktur, sistem yang akan dibangun ini harus dapat dijalankan dengan baik menggunakan perangkat keras maupun perangkat lunak yang relatif murah dibandingkan bila menggunakan perangkat khusus pengatur traffic komersial. Oleh karean hal tersebut, desain untuk penerapan sistem terdiri dari butir-butir berikut ini:

1. Sistem pengaturan dijalankan pada router yang dibangun dengan menggunakan perangkat keras komputer biasa, ditambah dengan sejumlah kartu jaringan (network interface), dan Sistem Operasi GNU/Linux. Disiplin antrian dan pengatur traffic utama adalah menggunakan Hierarchical Token Bucket (HTB), yang sudah termasuk di dalam kernel Linux.

2. Disiplin antrian untuk pengaturan dikaitkan pada network interface yang diperlukan, dimana paket keluar dari interface tersebut. Seperti rancangan sistem pada Gambar 1, disiplin antrian HTB yang bertugas untuk mengatur alokasi upload dari komputer client di jalankan di interface eth0 dan untuk downloadnya dijalankan dari interface eth1.

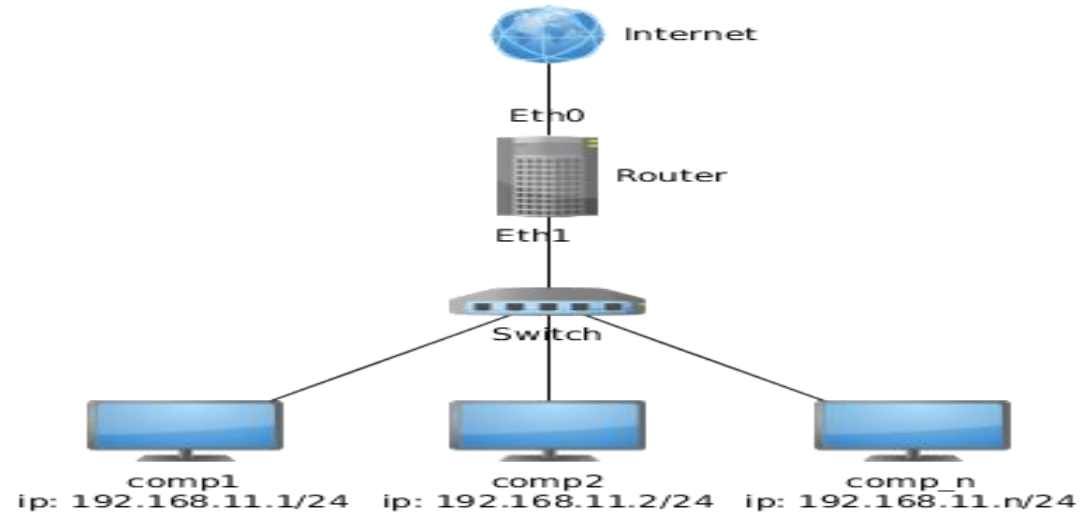

Gambar 1. Rancangan sistem manajemen bandwidth

3. Pengaturan dibuat untuk memastikan dan menjamin bahwa komputer client mendapatkan sesuai dengan kelasnya sendiri. Dengan disiplin antrian HTB, kelas penggunaan dibuat dengan nilai parameter rate $=$ alokasi minimum dan ceil $=$ alokasi maksimum. Untuk kelas penggunaan penuh, nilai rate $=$ nilai ceil. Pada penelitian ini akan dilakukan pembagian untuk 30 client dengan pembagian seperti pada Tabel 1 di bawah ini dengan alokasi total bandwidth yang disediakan adalah $512 \mathrm{kbit} / \mathrm{s}$ :

Tabel 1. Rencana implementasi pembagian bandwidth

\begin{tabular}{|c|c|c|c|c|c|}
\hline \multirow{2}{*}{ No } & \multirow{2}{*}{ PC Client } & \multicolumn{2}{c|}{ Download (Kbps) } & \multicolumn{2}{c|}{ Upload (Kbps) } \\
\cline { 3 - 6 } & & Rate & Ceil & Rate & Ceil \\
\hline 1 & 192.168 .11 .1 & 8 & 128 & 8 & 128 \\
\hline 2 & 192.168 .11 .2 & 8 & 128 & 8 & 128 \\
\hline 3 & 192.168 .11 .3 & 8 & 128 & 8 & 128 \\
\hline 4 & 192.168 .11 .4 & 8 & 128 & 8 & 128 \\
\hline 5 & 192.168 .11 .5 & 8 & 128 & 8 & 128 \\
\hline 6 & 192.168 .11 .6 & 8 & 128 & 8 & 128 \\
\hline 7 & 192.168 .11 .7 & 8 & 128 & 8 & 128 \\
\hline 8 & 192.168 .11 .8 & 8 & 128 & 8 & 128 \\
\hline 9 & 192.168 .11 .9 & 8 & 128 & 8 & 128 \\
\hline 10 & 192.168 .11 .10 & 8 & 128 & 8 & 128 \\
\hline 11 & 192.168 .11 .11 & 8 & 128 & 8 & 128 \\
\hline
\end{tabular}


Tabel 1 (lanjutan). Rencana implementasi pembagian bandwidth

\begin{tabular}{|c|c|c|c|c|c|}
\hline \multirow{2}{*}{ No } & \multirow{2}{*}{ PC Client } & \multicolumn{2}{c|}{ Download (Kbps) } & \multicolumn{2}{c|}{ Upload (Kbps) } \\
\cline { 3 - 6 } & & Rate & Ceil & Rate & Ceil \\
\hline 12 & 192.168 .11 .12 & 8 & 128 & 8 & 128 \\
\hline 13 & 192.168 .11 .13 & 8 & 128 & 8 & 128 \\
\hline 14 & 192.168 .11 .14 & 8 & 128 & 8 & 128 \\
\hline 15 & 192.168 .11 .15 & 8 & 128 & 8 & 128 \\
\hline 16 & 192.168 .11 .16 & 8 & 128 & 8 & 128 \\
\hline 17 & 192.168 .11 .17 & 8 & 128 & 8 & 128 \\
\hline 18 & 192.168 .11 .18 & 8 & 128 & 8 & 128 \\
\hline 19 & 192.168 .11 .19 & 8 & 128 & 8 & 128 \\
\hline 20 & 192.168 .11 .20 & 8 & 128 & 8 & 128 \\
\hline 21 & 192.168 .11 .21 & 8 & 128 & 8 & 128 \\
\hline 22 & 192.168 .11 .22 & 8 & 128 & 8 & 128 \\
\hline 23 & 192.168 .11 .23 & 8 & 128 & 8 & 128 \\
\hline 24 & 192.168 .11 .24 & 8 & 128 & 8 & 128 \\
\hline 25 & 192.168 .11 .25 & 8 & 128 & 8 & 128 \\
\hline 26 & 192.168 .11 .26 & 8 & 128 & 8 & 128 \\
\hline 27 & 192.168 .11 .27 & 8 & 128 & 8 & 128 \\
\hline 28 & 192.168 .11 .28 & 8 & 128 & 8 & 128 \\
\hline 29 & 192.168 .11 .29 & 8 & 128 & 8 & 128 \\
\hline 30 & 192.168 .11 .30 & 8 & 128 & 8 & 128 \\
\hline
\end{tabular}

4. Membuat filter dengan kriteria berdasarkan alamat IP asal paket data, IP tujuan, port asal, port tujuan atau nilai lain dalam header paket tcp/ip. Sebagai contoh, dengan program tc di Linux, alamat IP asal dan alamat IP tujuan dibuat sebagai nilai untuk parameter ip source atau ip destination tergantung dari arah traffic, untuk kemudian diberikan kepada kelas HTB yang sesuai dengan alokasi nya.

Setelah tahap rancangan diimplementasikan maka diperlukan pengujian sistem untuk mengetahui apakah sistem berjalan dengan semestinya atau tidak. Metode pengujian sistem dilakukan dengan membandingkan antara implementasi rancangan dengan hasil aktualnya. Untuk itu perlu sistem monitoring terhadap jalannya manajemen bandwidth yang dengan monitoring ini akan diperoleh data-data dan informasi aktual atas jalannya sistem manajemen bandwidth. Program tc bisa digunakan untuk menampilkan berbagai statistik dari setiap disiplin antrian, kelas dan filter yang diterapkan, termasuk jumlah paket data yang masuk ke dalam satu kelas tertentu. Dengan membuat sebuah program/script sederhana, nilai jumlah paket data ini bisa diambil secara periodik dan kemudian diberikan pada sebuah aplikasi berbasis web yang bisa digunakan untuk menampilkan grafik pemakaian dalam jaringan seperti Cacti (cacti.net) atau MRTG (oss.oetiker.ch/mrtg). Aplikasi-aplikasi ini memiliki kemampuan untuk menangani sejumlah sumber data (data sources) yang mengikuti format tertentu dan menampilkan datanya sebagai sebuah grafik dengan berbagai cara. Yang perlu dilakukan hanya menyiapkan sumber datanya dengan format yang dapat diproses oleh aplikasi tersebut. Untuk selanjutnya, implementasi dan pembahasan detil hanya sampai pada pengambilan data dari statistik HTB dan membuat hasilnya menjadi sumber data bagi aplikasi penampil grafik. Oleh karena itu dari hasil monitoring yang dilakukan dapat dilihat dari data yang didapat untuk membandingkan antara rancangan dengan hasil monitoringnya, apakah rancangan yang dibangun sesuai dengan hasil pada aktualnya atau tidak. Ketika hasil monitoring sudah mencerminkan kesesuaian dengan rancangan implementasi maka dapat dikatakan bahwa sistem berjalan sesuai dengan semestinya.

\section{HASIL DAN PEMBAHASAN}

\subsection{Implementasi Sistem}

Sistem pengaturan bandwidth dengan HTB di router meliputi pembuatan displin antrian utama HTB, class-class HTB, disiplin antrian (SFQ) untuk setiap class HTB, dan filter-filter untuk dikaitkan dengan class-class tersebut. 


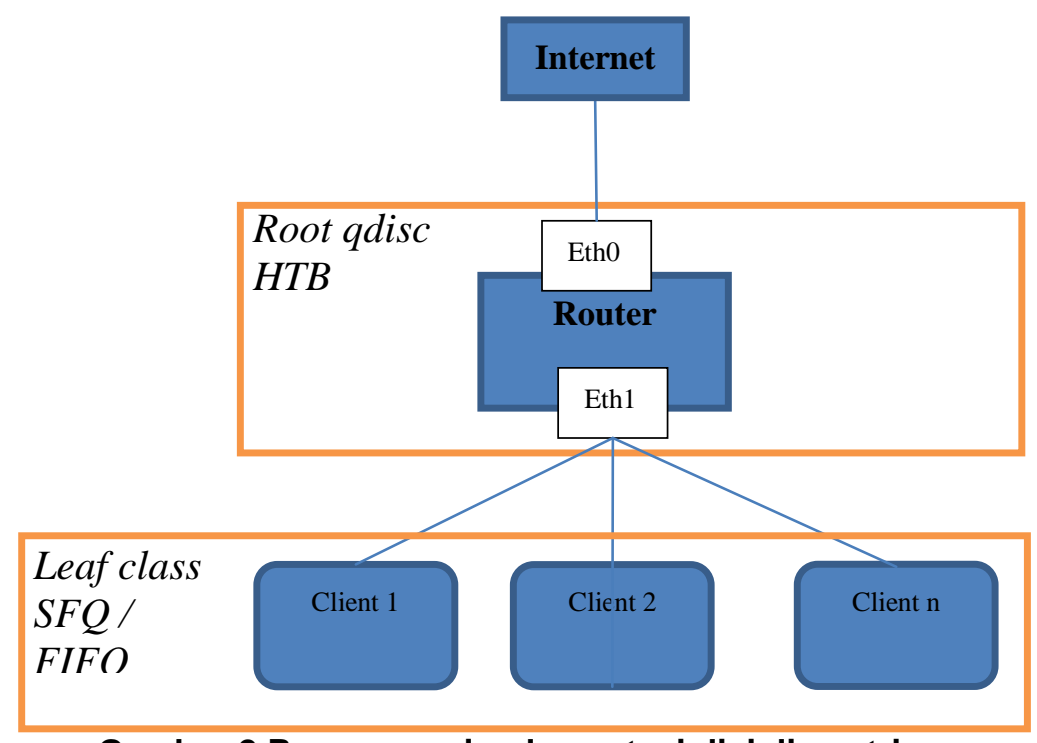

Gambar 2 Rancangan implementasi disiplin antrian

\title{
3.1.1. Disiplin Antrian HTB (HTB qdisc)
}

Pengaturan bandwidth dengan HTB dibangun pertama-tama dengan membuat sebuah root qdisc menggunakan program $t c$, yang akan menjadi disiplin antrian utama. Dengan demikian, root qdisc di router dibuat untuk 2 buah interface jaringan (etho dan eth1) dengan perintahperintah seperti berikut:

\author{
tc qdisc add dev eth0 root handle 1: htb default 30 \\ tc qdisc add dev eth1 root handle 1: htb default 30
}

Kedua perintah di atas menghasilkan 2 HTB qdisc yang dikaitkan pada interface eth0 dan eth1, dengan ID untuk class default adalah 30 . Kedua qdisc tersebut akan menjadi dasar pengaturan untuk traffic upload (keluar dari eth0) dan traffic download (keluar dari eth1) seperti pada Gambar 2 di atas.

\subsubsection{Kelas-kelas HTB (HTB class)}

Class-class HTB dibangun di bawah root qdisc yang telah dibuat sebelumnya. Di bawah root class ini dibuat lagi sejumlah class yang lain sesuai dengan hirarki yang dikehendaki. pada masing-masing interface dibuat satu root class dengan nilai rate dan ceil yang besar, sehingga root class ini seakan-akan adalah perangkat keras interface jaringan itu sendiri. Kemudian untuk class-class yang ada di bawah root class ada 3 class, antara lain : class Internet, class local, class default. Di bawah class internet juga terdiri lagi leaf class yang terdiri dari $\mathrm{n}$ leaf class dimana $n$ disini terdiri dari 30 dan ke 30 class ini merupakan class yang dimiliki oleh komputer-komputer client. Setiap leaf class atau class ujung yang tidak mempunyai anak class dibawahnya harus mempunyai sebuah classless qdisc yang secara langsung akan menangani proses antrian paket-paket data. Qdisc yang digunakan disini adalah SFQ. Bila untuk sebuah leaf class tidak ditentukan qdisc secara spesifik seperti di atas, maka kernel akan memberikan FIFO sebagai default qdisc. SFQ dipilih karena mempunyai kinerja yang baik dan adil, dan cocok untuk digunakan pada link-sharing dengan traffic yang cenderung penuh.

\subsection{Monitoring Sistem}

Monitoring terhadap sistem manajemen bandwidth bertujuan untuk mengetahui dan memastikan bahwa sistem ini berjalan sesuai dengan yang dikehendaki. Monitoring dilakukan dengan mengambil data-data kuantitatif dari statistik pengaturan HTB menggunakan program tc. Hasil yang diperoleh kemudian ditampikan dalam bentuk gambar grafik menggunakan program Cacti. Dengan kemampuan Cacti untuk menjalankan sebuah perintah atau script sebagai metode pengambilan datanya, maka script yang diberikan pada Cacti kemudian dieksekusi dari dalam proses aplikasi Cacti tersebut. Untuk memudahkan dalam mengelola dan menampilkan informasi secara menyeluruh, data dari router diambil oleh Cacti dengan bantuan paket program snmp dan snmp-server. Proses snmp-server memiliki fasilitas extend dan exec yang dapat digunakan untuk mengeksekusi perintah/script tertentu dalam sistem, dan 
memasukkan outputnya ke dalam struktur Management Information Base dengan SNMP ObjectID yang bisa dipilih atau dikehendaki. Dengan demikian, data monitoring bisa diambil dengan melakukan query atas SNMP ObjectID yang sudah ditentukan sebelumnya. Dalam hal ini, SNMP Server akan diminta untuk mengeksekusi script yang kita tentukan, setiap kali ada SNMP query dari Cacti, atas SNMP ObjectiD yang berisi data statistik class-class HTB di atas. Cacti akan terus menjalankan background proses di system dan akan melakukan query untuk mengambil data secara periodik dengan defaultnya yaitu setiap 300 detik. Dengan demikian akan diperoleh grafik monitoring traffic yang masuk ke dalam class-class pengaturan HTB yang sedang berjalan. Dalam proses monitoring yang dilakukan untuk analisis disini digunakan sample 6 PC client yang masing-masing diberikan alokasi rate $8 \mathrm{kbit} / \mathrm{s}$ dan ceil $128 \mathrm{kbit} / \mathrm{s}$ untuk traffic internet. 6 PC ini mempunyai satu class induk yaitu class inet dengan alokasi bandwidth 512 kbit/s. Pengamatan dilakukan selama rentang waktu sekitar 2 jam dengan setiap PC client mendownload file yang cukup besar dari sumber yang koneksinya cukup bagus dan lancar. Skenario pengambilan datanya adalah pertama-tama penggunaan traffic hanya dilakukan oleh comp1 dan comp2 sekitar 30 menit, kemudian penggunaan traffic ditambah dengan comp3. Setelah itu, 15 menit kemudian ditambah lagi dengan comp4. Kemudian setelah sekitar 45 menit, pemakaian ditambah dengan comp5 dan comp6 secara bersamaan selama 30 menit.

\subsection{Analisis Sistem}

Dari hasil monitoring yang sudah dilakukan grafiknya bisa dilihat dari gambar 3 berikut ini. Pada interval waktu 30 menit pertama comp1 dan comp2 masing-masing dapat menggunakan bandwidth sampai dengan $128 \mathrm{kbit} / \mathrm{s}$ meskipun alokasi rate untuk comp1 dan comp2 hanya 8 $\mathrm{kbit} / \mathrm{s}$. hal ini terjadi karena class induknya yang memiliki bandwidth $512 \mathrm{kbit} / \mathrm{s}$ masih memiliki sisa bandwidth dan dapat dipinjamkan kepada comp1 dan comp2. Dan pada grafik traffic inet selama sekitar 30 menit pertama class ini menggunakan traffic $256 \mathrm{kbit} / \mathrm{s}$ yang mana traffic tersebut adalah agregat dari 2 class anaknya yaitu comp1 dan comp2.
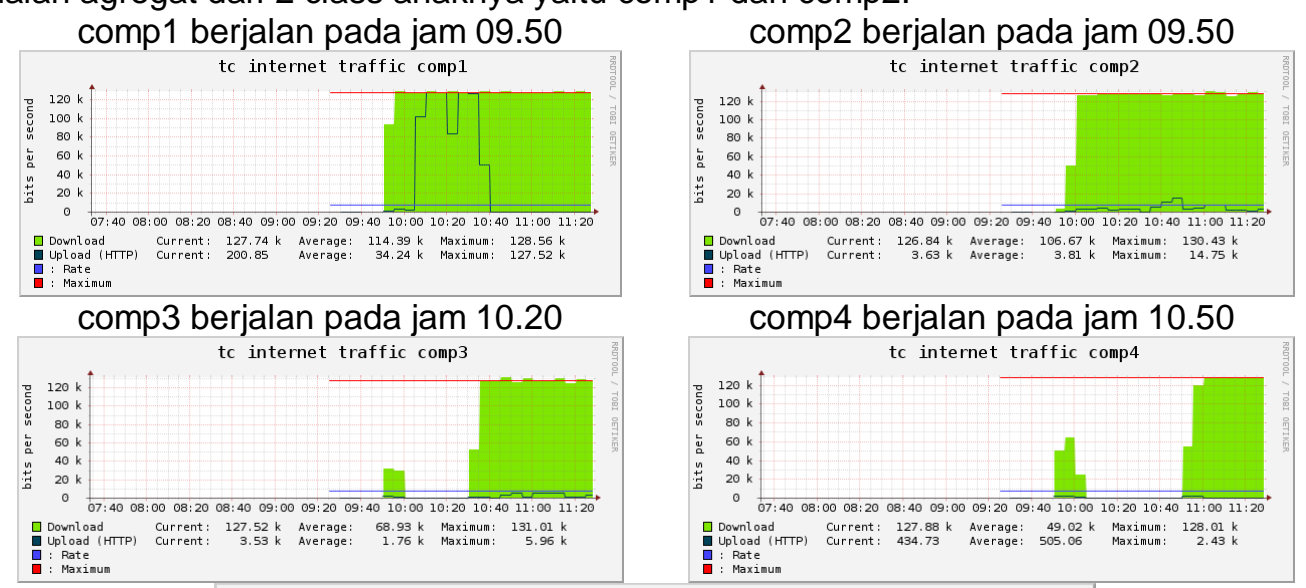

comp4 berjalan pada jam 10.50

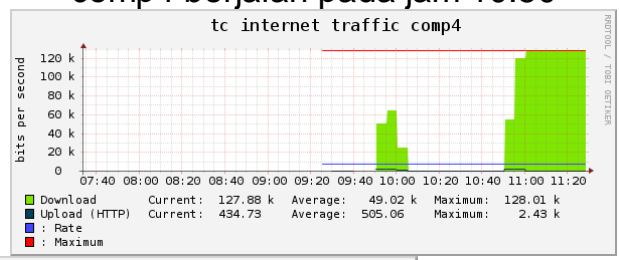

tc internet traffic inet

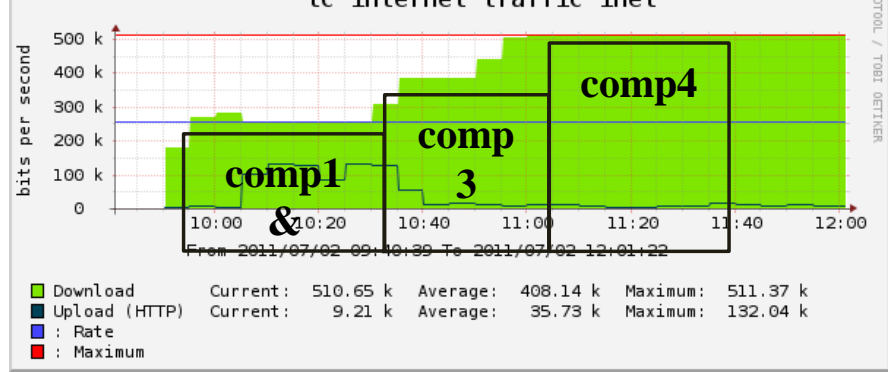

Gambar 3 Monitoring grafik comp1, comp2, comp3, comp4, dan inet awal

Kemudian pada interval waktu berikutnya comp3 mulai menggunakan traffic dan comp3 ini bisa menggunakan bandwidth samapai dengan ceil classnya yaitu $128 \mathrm{kbit} / \mathrm{s}$ karena class induknya yaitu class inet masih memiliki alokasi bandwidth sampai dengan $512 \mathrm{kbit} / \mathrm{s}$. Dan bisa dilihat juga pada grafik inet saat interval waktu setelah comp3 dinyalakan bahwa class inet mengalami kenaikan penggunaan bandwidth menggunakan bandwidth sekitar $384 \mathrm{kbit} / \mathrm{s}$ yang mana traffic tersebut adalah agregat dari 3 class anaknya yaitu comp1, comp2, dan comp3. Pada interval waktu berikutnya comp4 mulai menggunakan traffic dan comp4 pun masih bisa memperoleh 
bandwidth sampai dengan ceilnya yaitu $128 \mathrm{kbit} / \mathrm{s}$. Seperti pada interval sebelumnya, comp1, comp2, comp3, dan comp4 masih bisa menikmati bandwidth sampai dengan ceilnya $128 \mathrm{kbit} / \mathrm{s}$ karena class induknya yaitu class inet memiliki alokasi sampai dengan 512 kbit/s.

Pada interval waktu yang terakhir ini comp5 dan comp6 mulai menggunakan traffic internet sehingga ada 6 komputer yang menggunakan traffic. Pada interval ini semua komputer mengalami penurunan pemakaian bandwidth menjadi sekitar $85 \mathrm{kbit} / \mathrm{s}$. Dapat dilihat pada gambar 4 bahwa comp5 dan comp6 mendapatkan bandwidth dikisaran 85 kbit/s selain itu terjadi penurunan bandwidth juga pada comp1, comp2, comp3, dan comp4 yang dari awalnya mendapatkan bandwidth sekitar $128 \mathrm{kbit} / \mathrm{s}$ menjadi $85 \mathrm{kbit} / \mathrm{s}$. hal ini terjadi karena alokasi bandwidth class induknya yaitu class inet yang sebelumnya digunakan oleh comp1, comp2, comp3, dan comp4 harus dibagikan sebagian ke comp5 dan comp6 karena sebenarnya comp1, comp2, comp3, dan comp4 sudah memperoleh bandwidth sesuai dengan ratenya yaitu $8 \mathrm{kbit} / \mathrm{s}$ dan kelebihannya adalah pinjaman dari class induknya yang sedang tidak terpakai.
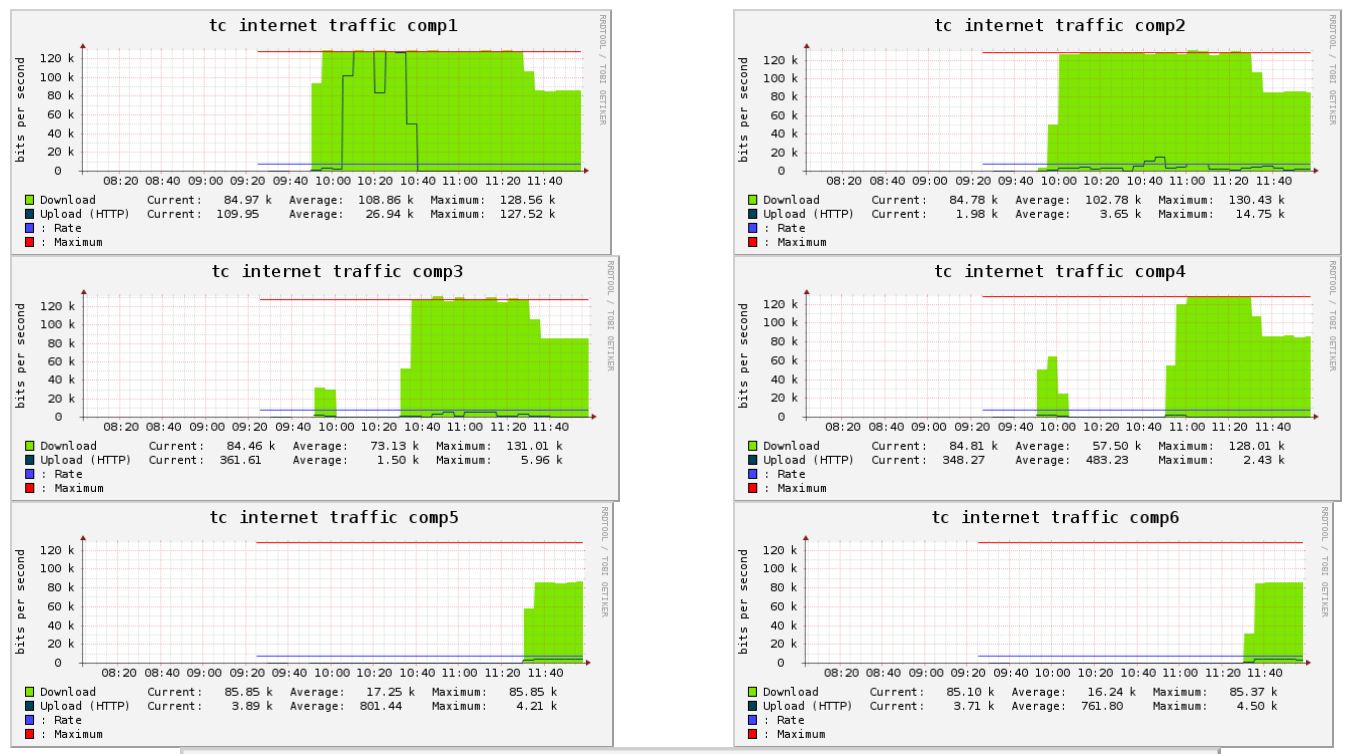

tc internet traffic inet

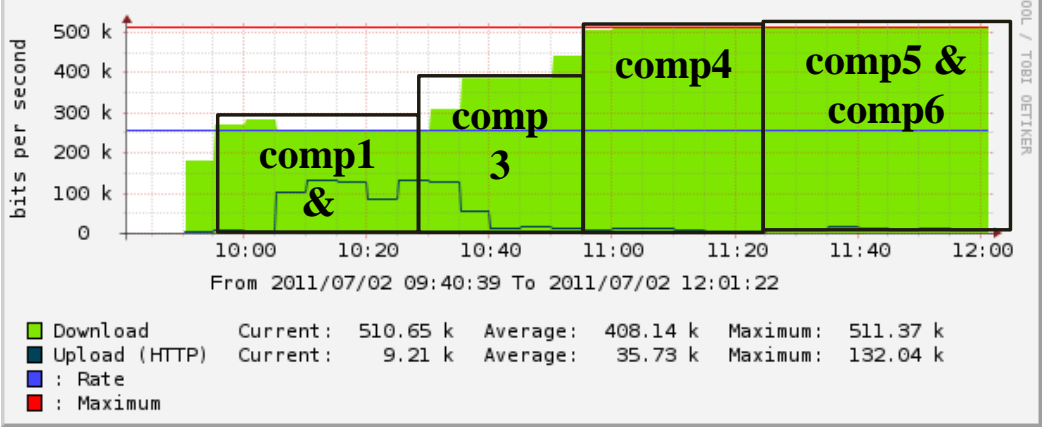

Gambar 4 Monitoring grafik 6 komputer client menggunakan bandwidth

Keadaan seperti di atas tersebut bandwidth yang tersedia dipinjamkan untuk 6 komputer. Setelah semua class anaknya (komputer 1 sampai 6) mendapatkan alokasi rate masing-masing (8 kbit/s) baru kemudian sisa alokasi bandwidthnya class induk dapat dipinjamkan / dibagikan kepada class-class anaknya. Dengan demikian, dapat dilihat bahwa setiap class pengaturan HTB untuk comp1, comp2, comp3, comp4, comp5, dan comp6 akan mendapatkan bandwidth sebesar alokasi rate yang ditentukan yaitu $8 \mathrm{kbit} / \mathrm{s}$ dan bisa memperoleh bandwidth lebih sampai dengan batas ceilnya yang ditentukan apabila class induknya masih memiliki sisa alokasi setelah semua rate class anaknya terpenuhi. 


\section{KESIMPULAN}

Implementasi manajemen bandwidth dengan disiplin antrian Hierarchical Token Bucket pada sistem operasi Linux dapat terealisasi sesuai dengan yang dirancang. Hasil monitoring traffic bandwith dapat membuktikan bahwa pengaturan bandwidth yang dibuat sudah sesuai dengan rancangan, yaitu pembatasan rate dan ceilnya sudah sesuai dengan pengaturan yang diatur oleh admin. Sehingga dengan terealisasinya hal tersebut tidak ada user atau client yang mendominasi dalam penggunaan bandwidth.

\section{DAFTAR PUSTAKA}

Devera, Martin; Cohen, Don., 2002. Hierarchical Token Bucket - Linux Queueing Discipline, $<$ http://luxik.cdi.cz/ devik/qos/htb/> , di akses pada tanggal 23 maret 2015.

Figgins, S., Siever, E., Weber, A. 2003. Linux in a Nutshell: O'Reilly \& Associates, Inc.

Floyd, S., Jacobson, V. 1995. Link-sharing and Resource Management Models for Packet Networks. IEEE/ACM Transactions on Networking, Vol. 3 No. 4.

Gabriel, D. \& Potorac, D.A. 2009. Linux HTB queuing discipline implementations. First International Conference on Networked Digital Technologies, pp. 122 - 126.

Ivancic, D., Hadjina, N., Basch, D. 2005. Analysis of precision of the HTB packet scheduler. Applied Electromagnetics and Communications, 2005.

Low, S.M. 2010. A Wireless Webcam-Based Robotic Vision System. Proc of International Conference on Intelligent and Advanced Systems (ICIAS), pp. 1-4.

Pramudita D.A., 2008. Implementasi Differentiated Service (Diffserv) Di Jaringan Testbed Menggunakan Disiplin Antrian Priority Queuing (PQ) dan Hierarchy Token Bucket (HTB). Skripsi Program Studi Teknik Elektro Institut Teknologi Bandung.

Purwaka, I.A., 2002. Perencanaan dan Implementasi Manajemen Proses Jaringan pada Warnet. Skripsi Program Studi Teknik Elektro Institut Teknologi Bandung.

Rusu, O., Subredu, M., Sparlea, I., Vraciu, V. 2002. Implementing Real Time Packet Forwarding Policies Using HTB. First RoEduNet International Conference, Cluj-Napoca, Romania, 2002. 